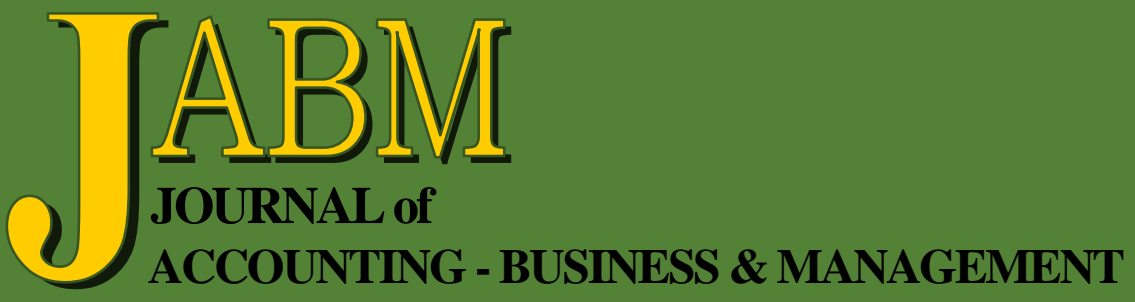

The Relationship between the Ownership Structure, Capital Structure and Performance

Ali Al-Thuneibat

The Effect of Self Efficacy and Information Quality on Behavioral Intention with Perceived Usefulness as Intervening Variable

Muslichah

Empirical Analysis of Factors Influencing Use of Internet on Ships

A. S. Saravanan, Jayalakshmy Ramachandran, A. Seetharaman, Karripur Nandakumar, and Capt. Kailash C. Joshi

Pawnshops Regulatory Environment: A Readability Analysis

Geralyn Miller, Steven A. Hanke, and Hui Di

Auditor Litigation and the Penalties on U.S. Client Firms after the Private Securities Litigation Reform Act

Nana Y. Amoah, Anthony Anderson, Isaac Bonaparte and Kyle Meyer 
Journal of Accounting - Business \& Management vol. 25 no. 1 (2018) 50-61

\title{
Pawnshops Regulatory Environment: A Readability Analysis
}

\author{
Geralyn Miller* \\ Steven A. Hanke† \\ Hui Dił
}

\begin{abstract}
The pawn industry in the United States grew substantially in recent years; however, there is limited research on the regulatory environment for these predominately small businesses. Our study focuses on the readability of state regulations for pawnshops. We select credit unions as a comparison group since they also service non-bank customers. Our analysis reveals that the majority of states' pawnbroker regulations are at the college reading level while the regulations for credit unions are at the college graduate reading level. There are also geographical differences in the readability of pawnshop regulations with the regulations in the northeast region being easier to read than in the west region. However, there is no evidence that the regulations readability level corresponds to the number of pawnbrokers in a state or to more broad-based measures of state-level business friendliness.
\end{abstract}

Keywords: pawnshop, readability, small business, regulation.

\section{INTRODUCTION}

The number of pawnbrokers has increased in the United States from 7,955 in 2007 to 10,283 in 2012 (U.S. Economic Census, 2017). This represents significant growth for a segment of small businesses given that $85 \%$ of pawn stores are independently owned according to the National Pawnbrokers Association. What factors contributed to such rapid growth? Bos et al. (2012) attributes the growth to the financial crisis starting in 2007 and a surge in the price of gold, a common pawn collateral item. Meanwhile, it is widely perceived that regulations are detrimental for economic growth. The National Small Business Poll (2017) by the National Federation of Independent Business shows that $49 \%$ of small business owners cited a "very serious" or "somewhat serious" impact of regulations on their businesses.

A 2013 Small Business Survey by Rhode Island provides evidence of regulations' impact. It finds that $37.3 \%$ of respondents paid outside consultants for assistance in navigating and complying with regulations (Rhode Island, 2013a). Rhode Island's Office of Regulatory Reform then identified readability, measured by the Flesch Readability Ease (FRE) score, as a barrier hindering the ease of access to regulations (Rhode Island, 2013b). We are unaware of any study that assesses variation of

\footnotetext{
* Associate Professor of Business Administration and Management, Department of Management and Marketing, Doermer School of Business. Indiana University, Purdue University Fort Wayne. Neff Hall 340. 2101 E. Coliseum Boulevard. Fort Wayne, IN 46805. E-mail: millergm@ipfw.edu.

$\dagger$ Associate Professor of Accounting, Department of Accounting and Finance, Doermer School of Business. Indiana University, Purdue University Fort Wayne. Neff Hall 350. 2101 E. Coliseum Boulevard. Fort Wayne, IN 46805. E-mail: hankes@ipfw.edu.

$\star$ Associate Professor of Finance, Department of Accounting and Finance, Doermer School of Business. Indiana University, Purdue University Fort Wayne. Neff Hall 350. 2101 E. Coliseum Boulevard. Fort Wayne, IN 46805. E-mail: dih@ipfw.edu.
} 
readability scores for state-level small business regulations. Our study seeks to fill this void by making the assessment within the pawn industry.

To provide an in-depth understanding of the pawn industry's regulatory environment, we compare the readability of its state regulations to that of state regulations faced by credit unions. The selection of credit unions as a comparison group is due to their explicit focus on serving low to moderate-income consumers who traditionally use pawnshops (Burger \& Zellmer, 1995). It is therefore not surprising that $76 \%$ of 50 largest credit unions offer free checking, more than twice the proportion of the banks with free checking service (Bell, 2016). At the same time, credit unions are generally larger in regards to financial resources with $\$ 65$ billion revenue from 19,942 businesses compared to \$6 billion from 11,190 pawnshop businesses, per IBISWorld's 2017 statistics. Credit unions also have more human resources with 298,875 employees in 19,942 businesses compared to 26,896 employees for in 11,190 pawnbroker businesses (IBISWorld, 2017). With more financial and human resources, credit unions should be able to better understand and comply with state regulations.

To the best of our knowledge, this is the first empirical study of the readability of state regulations for either pawnbrokers or credit unions. Prior pawnshop research is limited to the impact of differences in state-level financing/profit restrictions (e.g., Caskey, 1991) or an in-depth understanding of pawnshop customers (e.g., Johnson \& Johnson, 1998). Moreover, the only prior test of geographical differences in readability is an examination of state income tax instructions by Urbancic and Hsu (2007). Relying on a sample of 42 states with regulations dedicated to both pawnbrokers and credit unions, our study allows for the first test of variation within the readability across states for small business dominated industry (pawnbrokers) and non-small business industry (credit unions).

Our study concludes with an assessment of whether the readability of pawnshop regulations are unique from more broad-based measures of the business climate in each of the states. We compare each state's readability score of pawnbroker regulations with its corresponding overall ranking based on the CNBC America's Top States for Business 2016 listing. The overall ranking is based on ten different categories including Business Friendliness, Cost of Doing Business and Infrastructure (CNBC, 2016). Among them, Business Friendliness is specifically relevant to our study since it captures the freedom of a state's regulatory framework. We further test if the Business Friendliness score for each state is a reasonable proxy for the readability of its pawnshop regulations.

Our findings present insights into the readability of pawnshop regulations. The majority of states have regulations that are written at the College reading level. Moreover, these states' regulations are closer to College Graduate level than the $10^{\text {th }}$ to $12^{\text {th }}$ Grade reading level. We do not find a significant relationship between states regulations readability level and the corresponding number of pawnbrokers in the state. Instead, a geographical difference is observed: pawnshop regulations in the Northeast region are easier to read than those in the West region. There is also evidence that the patterns of pawnshop regulations readability are unique from other seemingly relevant proxies. For example, the majority of credit union regulations are at the College Graduate readability level. This result holds when examining the readability by states or by geographical regions. Additional tests reveal that the readability of state pawnbroker regulations is not correlated with more broad-based measures of state-level business environments. This is further evidence that the pawn industry faces a unique regulatory environment. 


\section{RELEVANT LITERATURE}

\subsection{Pawn Industry}

Despite the magnitude of the pawn industry, it has received little attention within academic studies. For example, Caskey (1991) notes a fifty-year gap between his study and the previous study to use data from North American pawn industry. Caskey focuses on the reasons behind geographic establishments of pawnshops and finds that differences in state usury ceilings are the primary reason for the uneven distribution of pawnshops across the nation. Shackman and Tenney (2006) extend this area of research by demonstrating that two sets of state regulations can have a negative impact on the number of existing pawnshops. The state regulations examined in the prior study are regarding interest rate ceilings and requirement to return excess proceeds from the sale of collateral items.

Another line of research is concerned with understanding the customers of pawnshops. Johnson and Johnson (1998) analyze 1,820 questionnaires completed by customers at nine different pawnshops in six different states. They conclude that pawnshop borrowers generally have lower levels of income, stability in employment, health insurance, education and experience with finance than non-borrowing pawnshop consumers. Bos et al. (2012) extends this line of research by assessing the social and financial background of pawnshop borrowers in the U.S. and Sweden. They find similar characteristics between the pawnshop borrowers of the two countries including being at an age when forming their own families, instability in job and marital status, lower income and bad credit scores.

\subsection{Small Business Success}

Although prior research addresses geographic establishments of pawnbrokers and characteristics of pawn borrowers, there is a void in the literature regarding the challenges and characteristics of the pawnshop owners. Given that the majority of pawnbrokers independently own their businesses, it is reasonable to assume that they face many of the same business environment challenges as their small business owner counterparts. We therefore rely on small business research for guidance on a further understanding of pawnshop owners.

Rogoff et al. (2004) reports that $29.2 \%$ of a broad sample of 236 small business owners viewed government regulations as a barrier to success. Researchers share a common perception that policy makers need to find ways to help reduce the barrier created by regulations for small business to form and/or expand (e.g., Liang \& Dunn, 2014). Campbell et al. (2012) find that the variation between state policies regarding economic freedom influence not only the births but also the deaths of firms. ${ }^{1}$ These

\footnotetext{
${ }^{1}$ In the current study, the Economic Freedom of North America (EFNA) produced by the Fraser Institute in Campbell et al. (2012) is not an applicable broad-based measure of statelevel business environment alternative to the CNBC rankings. There are two EFNA indices: subnational index and all-government index. The subnational index includes minimum wage legislation, government employment and union density while all-government index expands the subnational index to include factors such as credit market regulations and business regulations. Our study did not include EFNA subnational index since it does not include business regulations. At first glance the all-government index seems appropriate for our study, however, the Fraser Institute (2016) states that it is not intended for within country analysis. Considering our analysis involves a single country, we do not include EFNA all-government index in the current study.
} 
studies highlight the potential impact and variation of state regulations regarding small businesses.

The ability of a small business to navigate regulations and succeed is often a function of not only its financial but also its human capital. The larger organizational structure of credit unions relative to pawnbrokers indicates the capability to access more financial and human capital to handle state regulations. It is therefore important to examine the literature on potential ramifications of these differences. The focus on the readability of regulations leads our study to focus on the availability of human capital. The characteristics of human capital commonly examined in prior research of small business owners include extent of education, age, experience in the same business area, trade apprenticeships, professional qualifications, etc.

Ganotakis (2012) finds that new technology firms perform better when their entrepreneurs or entrepreneurial teams have high levels of formal education. As to why further education may enhance business performance, Coleman (2004) reports that more highly educated owners were less likely to need bank loans but more likely to get them when applied for. Chandler and Hanks (1998) document that a higher level of human capital allows business founders to compete successfully even with lower levels of financial capital. More highly educated self-employed achieve higher growth in both economic expansion and retraction periods (Kangasharju \& Pekkala, 2002).

At the same time, an entrepreneur's formal education does not guarantee business success. Baptista et al. (2014) document a limited impact of education on business survival, that is, an entrepreneur being a university graduate significantly increases the probability of surviving the critical first three years only for those who were unemployed prior to startup. Lussier (1995) finds that the sample of unsuccessful firms has a greater amount of education than that of successful firms. There is evidence that small business owners can take measures to mitigate their weak education background. With help of external advisers, entrepreneurs without college education can be more successful than those with college degrees (Coy \& Shipley, 2004). Based on a meta-analysis of 70 studies on how human capital impacts entrepreneurial success, Unger et al. (2011) conclude that past indicators of human capital (e.g., extent of college education) are not as predictive of success as having a learning process in place to acquire new knowledge in a continuously changing business environment.

\subsection{Readability of Regulations}

Our review of prior research shows the potential impact of small business owners' ability to navigate regulations and their education levels on business success. By the logic, a prudent government policy would be to have regulations written at a level that could be understood by a larger portion of the small business owners. This would potentially increase the ability of more small businesses to succeed. Partially driven by such policy ambitions, there is a long history of interest in the readability of government documents. One example is a 1978 General Accounting Office (GAO, 1994) report calling for improved readability of I.R.S. tax forms and publications. A continuing effort on the policy objective is evidenced by passage of the Plain Writing Act on October 13, 2010. This legislation requires all federal communications to be written in "plain" English to increase their understandability.

The FRE score, a common measure of readability, is calculated as 206.835 (1.015 $\times$ average number of words per sentence) - (84.6×average syllables per word). Though other factors may influence a document's readability, adding factors beyond those captured in the FRE score brings minimal benefit (Klare, 1974). The FRE score 
can be easily obtained given its availability in Microsoft Word (Microsoft.com, 2010). The readability measure ranges between zero and 100 and a lower number indicates that the document is more difficult to read. Table 1 summarizes the score ranges and their corresponding school levels.

Table 1

Summary of FRE Score Ranges

\begin{tabular}{lll}
\hline FRE Score & \multicolumn{1}{c}{ Reading Level } & \multicolumn{1}{c}{ Notes } \\
\hline $\mathbf{0 . 0}-\mathbf{3 0 . 0}$ & College Graduate & Very difficult to read \\
$\mathbf{3 0 . 0 - 5 0 . 0}$ & College & Difficult to read \\
$\mathbf{5 0 . 0 - 6 0 . 0}$ & $10^{\text {th }}$ to $12^{\text {th }}$ grade & Fairly difficult to read \\
$\mathbf{6 0 . 0 - 7 0 . 0}$ & $8^{\text {th }} \& 9^{\text {th }}$ grade & Plain English \\
$\mathbf{7 0 . 0 - 8 0 . 0}$ & $7^{\text {th }}$ grade & Fairly easy to read \\
$\mathbf{8 0 . 0 - 9 0 . 0}$ & $6^{\text {th }}$ grade & Easy to read \\
$\mathbf{9 0 . 0 - 1 0 0 . 0}$ & $5^{\text {th }}$ grade & Very easy to read \\
\hline
\end{tabular}

Prior studies provide evidence that the readability of regulations/legal guidance may vary between geographical locations and seemingly closely related topics. Urbancic and Hsu (2007) find that there is a geographical influence on the readability of state income tax instructions with those in the West region being the easiest to read (FRE score of 53.5) and those in the South being the most difficult (FRE Score of 46.9). Hanke et al. (2012) report that the readability of Tax Court cases citing sections of Internal Revenue Code (I.R.C.) sections related to Retirement Savings Accounts (RSA) are significantly different than cases citing I.R.C. sections regarding General Financial Planning (GFP) in three out of five decades from the 1960s through the 2000s. Although both of these studies focus on income tax regulations and related legal precedence, they highlight the potential differences within regulations due to geographical location and specific topics covered within

\section{DATA COLLECTION}

The National Pawnbrokers Association and the Credit Union National Association maintain repositories with links to each of the states' regulations in both areas. $^{2}$ In cases where the links were missing, the individual acts were accessed through Google searches of the specific statutes using the particular missing state's name along with a phrase of either "Pawnbroker Act" or "Credit Union Act". Missing state statutes were, particularly, important on the pawnbroker side of the data since the states vary considerably in their licensing requirements. Some states leave the licensing and regulations of these establishments up to the individual county or municipal ordinances. ${ }^{3}$ Furthermore, several states were omitted from the dataset because their licensing requirement language was either non-existent or inadequate for assessment of readability. Some of these states only specify that the regulation of pawnshops falls

2 The links to state-level laws for pawnbrokers and credit unions can be found at https://www.google.com/maps/d/viewer?mid=1FsLuNZFW9yp4UQuUhQJN4dgCbD4\&ll $=42.457984957003205 \% 2 \mathrm{C}-113.8191845 \& z=4$ and the Credit Union National Association (CUNA) at https://www.cuna.org/Legislative-And-Regulatory-Advocacy/State-Government -Affairs/State-Government/State-Credit-Union-Acts/, respectively.

3 The states that did not have existing statutes were Arkansas. Idaho, Iowa, New York, and North Dakota. 
under the domain of the individual counties. In those cases, the statutory language is simply a reference and does not have enough information to generate a readability score. Our sample consists of the regulations for pawnshops and credit unions available for 42 states.

\section{RESULT}

To assess the readability, we obtain the FRE score for each regulation through the Grammar option in Microsoft Word. Our analysis of readability scores starts with the state regulations of pawnshops as shown in Panel A of Table 2. The mean readability score of state-level pawnbroker regulations is 34.10 and falls in the College level. Among 42 states, 32 states have pawnbroker regulations with the College-level readability scores. Further, the pawnshop regulations with College reading level have a dispersed distribution within the range of the readability scores. Massachusetts is the only state in the range of 45.0 to 50.0 while there are 19 states in the range of 30.0 to 35.0. Thus, the majority of the states in the College level range are closer to having readability scores near the College Graduate level rather than the $10^{\text {th }}$ to $12^{\text {th }}$ Grade level.

Insert Table 2 here.

Wisconsin has the easiest to read state regulations for pawnshops. With its FRE score of 54.2 falling into the $10^{\text {th }}$ to $12^{\text {th }}$ Grade reading level, it is the only state with pawnshop regulations readability level being below the College level. Meanwhile, there are nine states with pawnbroker readability scores in the College Graduate level with Missouri having the most difficult to read regulations. One plausible explanation for the variation of state-level pawnbroker regulations readability scores might be the number of pawnshops in each state. Untabulated results reveal no significant relationship between the number of pawnshops in each state and its corresponding state-level pawnshop regulations readability score.

Credit union regulations, as summarized in Panel B of Table 2, are more difficult to read than pawnshop regulations. The mean FRE score of 28.78 is at the College Graduate level. This is not surprising since there are 25 of 42 states with a College Graduate reading levels. Maine has the highest FRE Score with 40.8, which by comparison would rank seventh based on pawnshop regulations.

We explore the potential "state-level" impact on similarity of readability scores for pawnshops and credit unions. Specifically, each state's readability level is categorized as $10^{\text {th }}$ to $12^{\text {th }}$ Grade, College or College Graduate and then we compare the category levels between pawnshops and credit unions. There are 21 states with pawnshop readability scores being in a less difficult category than their credit union counterparts. Among them, Rhode Island deserves special attention given the state government's explicitly stated interest in readability scores for small business regulations (Rhode Island, 2013b). We find that Rhode Island has a College-level FRE score of 39.9 for pawnshops and a College Graduate-level score of 25.9 for credit unions. Seventeen states' readability levels are in the same categories for both types of businesses. Meanwhile, there are only four states with credit union regulations being an easier to read category than pawnshops. Overall, it appears that the regulations for pawnbrokers are relatively easier to read than the ones for credit unions despite their similar clientele. Following the logic in Rhode Island (2013b), this should reduce the likelihood of pawnbrokers needing to hire external consultants for regulatory compliance purposes. Small businesses can benefit from easier-to-read regulations due to their limited financial resources. 
Table 2

Readability of State Regulations

\begin{tabular}{|c|c|c|c|c|c|}
\hline \multicolumn{3}{|c|}{ Panel A: Pawnshop Regulations } & \multicolumn{3}{|c|}{ Panel B: Credit Union Regulations } \\
\hline State & $\begin{array}{l}\text { FRE } \\
\text { Score }\end{array}$ & $\begin{array}{c}\text { Reading } \\
\text { Level }\end{array}$ & State & $\begin{array}{l}\text { FRE } \\
\text { Score }\end{array}$ & $\begin{array}{c}\text { Reading } \\
\text { Level }\end{array}$ \\
\hline Wisconsin & 54.2 & $10^{\text {th }}$ to $12^{\text {th }}$ Grade & Maine & 40.8 & \multirow{17}{*}{ College } \\
\hline Massachusetts & 49.9 & \multirow{32}{*}{ College } & North Carolina & 37 & \\
\hline Kansas & 43.5 & & Alaska & 36.3 & \\
\hline Alabama & 42 & & Wisconsin & 35.7 & \\
\hline Vermont & 41.9 & & Pennsylvania & 34.8 & \\
\hline Nevada & 41.3 & & Maryland & 34.8 & \\
\hline Michigan & 40.2 & & Tennessee & 34.6 & \\
\hline Rhode Island & 39.9 & & Minnesota & 34 & \\
\hline North Carolina & 39.5 & & Utah & 33.4 & \\
\hline Nebraska & 39.4 & & West Virginia & 32.9 & \\
\hline Maine & 38.5 & & Texas & 32.5 & \\
\hline Texas & 38.2 & & Nevada & 32.3 & \\
\hline Louisiana & 35.6 & & Indiana & 31.8 & \\
\hline South Carolina & 35.5 & & Hawaii & 31.6 & \\
\hline Pennsylvania & 35 & & Oklahoma & 31.4 & \\
\hline Arizona & 34.9 & & Nebraska & 30.3 & \\
\hline Maryland & 34.8 & & Georgia & 30.2 & \\
\hline Virginia & 34.6 & & South Carolina & 29.5 & \multirow{25}{*}{$\begin{array}{l}\text { College } \\
\text { Graduate }\end{array}$} \\
\hline Montana & 34.5 & & New Jersey & 29.4 & \\
\hline Georgia & 34 & & Michigan & 29.2 & \\
\hline Washington & 34 & & Florida & 28.6 & \\
\hline New Jersey & 33.5 & & New Hampshire & 27.9 & \\
\hline Oregon & 33.2 & & Arizona & 27.5 & \\
\hline Florida & 32.5 & & Kansas & 27 & \\
\hline Minnesota & 31.8 & & Colorado & 27 & \\
\hline Utah & 31.8 & & Kentucky & 26.7 & \\
\hline New Hampshire & 31.7 & & Vermont & 26.3 & \\
\hline Tennessee & 31.6 & & Massachusetts & 26.2 & \\
\hline Oklahoma & 31.5 & & Montana & 26.2 & \\
\hline New Mexico & 31.5 & & Mississippi & 26.1 & \\
\hline Connecticut & 31.2 & & New Mexico & 26 & \\
\hline Illinois & 31 & & Rhode Island & 25.9 & \\
\hline Mississippi & 30.2 & & Louisiana & 25.2 & \\
\hline Kentucky & 29.8 & \multirow{9}{*}{$\begin{array}{l}\text { College } \\
\text { Graduate }\end{array}$} & Virginia & 24.7 & \\
\hline Alaska & 28.1 & & Illinois & 24.5 & \\
\hline West Virginia & 28 & & Oregon & 24.3 & \\
\hline Ohio & 26.9 & & Washington & 23.9 & \\
\hline Indiana & 25.2 & & Connecticut & 22.6 & \\
\hline Colorado & 24.5 & & Alabama & 21.5 & \\
\hline California & 24.1 & & Missouri & 20.4 & \\
\hline Hawaii & 22.1 & & Ohio & 20.3 & \\
\hline Missouri & 20.6 & & California & 17.3 & \\
\hline Mean & 34.10 & College & Mean & 28.78 & $\begin{array}{l}\text { College } \\
\text { Graduate }\end{array}$ \\
\hline
\end{tabular}

We next analyze if there is a geographical impact on readability scores. Table 3 reports the mean readability scores for pawnbroker and credit union regulations by region as defined by the U.S. Census Bureau. Similar to the state-level impacts discussed above, we find that each region's pawnshop regulations are at the College 
reading level while the credit union regulations are at the College Graduate reading level. Table 3 reveals a geographical impact on the readability of pawnbroker regulations with a substantial difference between the Northeast region with the highest mean FRE score of 37.7 and the West region with the lowest mean score of 30.9. In contrast, the credit union regulations have similar readability scores across all regions with the highest FRE score of 29.7 in the South region and the lowest FRE score of 27.8 in the West region.

Table 3

Comparisons of State Regulations Readability by Regions

\begin{tabular}{|c|c|c|c|}
\hline & \multicolumn{2}{|c|}{ FRE Score } & \multirow{2}{*}{$\begin{array}{c}\text { Difference in FRE Scores } \\
\text { (Pawnshops - Credit Unions }\end{array}$} \\
\hline & Pawnshops & Credit Unions & \\
\hline \multicolumn{4}{|c|}{ Region 1: Northeast } \\
\hline Massachusetts & 49.9 & 26.2 & 23.7 \\
\hline Vermont & 41.9 & 26.3 & 15.6 \\
\hline Rhode Island & 39.9 & 25.9 & 14 \\
\hline Connecticut & 31.2 & 22.6 & 8.6 \\
\hline New Jersey & 33.5 & 29.4 & 4.1 \\
\hline New Hampshire & 31.7 & 27.9 & 3.8 \\
\hline Pennsylvania & 35 & 34.8 & 0.2 \\
\hline Maine & 38.5 & 40.8 & -2.3 \\
\hline Mean & 37.7 & 29.2 & 8.5 \\
\hline \multicolumn{4}{|c|}{ Region 2: Midwest } \\
\hline Wisconsin & 54.2 & 35.7 & 18.5 \\
\hline Kansas & 43.5 & 27 & 16.5 \\
\hline Michigan & 40.2 & 29.2 & 11 \\
\hline Nebraska & 39.4 & 30.3 & 9.1 \\
\hline Ohio & 26.9 & 20.3 & 6.6 \\
\hline Illinois & 31 & 24.5 & 6.5 \\
\hline Missouri & 20.6 & 20.4 & 0.2 \\
\hline Minnesota & 31.8 & 34 & -2.2 \\
\hline Indiana & 25.2 & 31.8 & -6.6 \\
\hline Mean & 34.8 & 28.1 & 6.6 \\
\hline \multicolumn{4}{|c|}{ Region 3: South } \\
\hline Alabama & 42 & 21.5 & 20.5 \\
\hline Louisiana & 35.6 & 25.2 & 10.4 \\
\hline Virginia & 34.6 & 24.7 & 9.9 \\
\hline South Carolina & 35.5 & 29.5 & 6 \\
\hline Texas & 38.2 & 32.5 & 5.7 \\
\hline Mississippi & 30.2 & 26.1 & 4.1 \\
\hline Florida & 32.5 & 28.6 & 3.9 \\
\hline Georgia & 34 & 30.2 & 3.8 \\
\hline Kentucky & 29.8 & 26.7 & 3.1 \\
\hline North Carolina & 39.5 & 37 & 2.5 \\
\hline Oklahoma & 31.5 & 31.4 & 0.1 \\
\hline Maryland & 34.8 & 34.8 & 0 \\
\hline Tennessee & 31.6 & 34.6 & -3 \\
\hline West Virginia & 28 & 32.9 & -4.9 \\
\hline Mean & 34.1 & 29.7 & 4.4 \\
\hline
\end{tabular}


To be continue from Table 3

\begin{tabular}{|c|c|c|c|}
\hline & \multicolumn{2}{|c|}{ FRE Score } & \multirow{2}{*}{$\begin{array}{l}\text { Difference in FRE Scores } \\
\text { (Pawnshops - Credit Unions) }\end{array}$} \\
\hline & Pawnshops & Credit Unions & \\
\hline \multicolumn{4}{|c|}{ Region 4: West } \\
\hline Washington & 34 & 23.9 & 10.1 \\
\hline Nevada & 41.3 & 32.3 & 9 \\
\hline Oregon & 33.2 & 24.3 & 8.9 \\
\hline Montana & 34.5 & 26.2 & 8.3 \\
\hline Arizona & 34.9 & 27.5 & 7.4 \\
\hline California & 24.1 & 17.3 & 6.8 \\
\hline New Mexico & 31.5 & 26 & 5.5 \\
\hline Utah & 31.8 & 33.4 & -1.6 \\
\hline Colorado & 24.5 & 27 & -2.5 \\
\hline Alaska & 28.1 & 36.3 & -8.2 \\
\hline Hawaii & 22.1 & 31.6 & -9.5 \\
\hline Mean & 30.9 & 27.8 & 3.1 \\
\hline
\end{tabular}

We use the Wilcoxon Signed-Ranks tests to examine the difference in the readability of pawnbroker and credit union regulations. Table 4 shows statistically significant differences in the readability scores of pawnbroker and credit union regulations in our full sample. When examining the difference in regulations readability within each region, we find statistically significant differences in the readability scores of pawnbroker and credit union regulations in three of the four regions. The West region is the only one with no significant difference in the readability scores of pawnshops and credit unions. This is consistent with our earlier result in Table 3 that the West region has the smallest difference in the readability of pawnshop regulations and credit union regulations. Further, we use the Wilcoxon-Mann-Whitney test to examine the readability of pawnshop regulations and credit union regulations separately by regions. The untabulated results show a significant difference in the readability of pawnbroker regulations only between the West region (lowest FRE score) and Northeast region (highest FRE score). Meanwhile, per untabulated results, we find no significant differences in the readability of the credit union regulations between regions.

Table 4

Wilcoxon Signed-Ranks Tests for Regulation Readability Comparisons of Pawnshop vs. Credit Unions by Regions

\begin{tabular}{lccccc}
\hline & Northeast & Midwest & South & West & Full Sample \\
\hline Two-tail test & $0.0234^{* *}$ & $0.0586^{*}$ & $0.0134^{* *}$ & 0.2402 & $0.0001^{* * *}$ \\
One-tail test & $0.0117^{* *}$ & $0.0293^{* *}$ & $0.0067^{* * *}$ & 0.1201 & $0.0000^{* * *}$ \\
\hline
\end{tabular}

Notes: $*, * *$, and $* * *$ indicate the statistical significance at $10 \%, 5 \%$, and $1 \%$, respectively.

Our results establish a pattern of considerable variance in the readability of state regulations between pawnshops and credit unions along with substantial differences in the readability of pawnshop regulations between geographical regions. We next test whether these patterns are consistent with other indicators of a state's business environments. To address this question, we compare the pawnbroker readability scores with the corresponding overall ranking by the CNBC America's Top States for Business 2016 and the ranking in the Business Friendliness subcategory. Untabulated results show no significant relationship between the pawnbroker readability scores and either ranking. This finding suggests that the challenges faced by pawnbrokers may not fully be captured in the popular measure of business environment. 


\section{CONCLUSION}

The pawnbroker industry has seen substantial growth over the past decade. At the same time, there is little known about the regulatory environment that these predominately small businesses encounter. This study, to the best of our knowledge, is the first to analyze the readability of state regulations for pawnshops. We find that these regulations are normally at the College reading level but are generally close to being at the College Graduate level. Moreover, the readability of the regulations varies based on the location of the pawnbrokers but is not correlated with the number of pawnbrokers in a given state. Our study also documents that the patterns of pawnshop regulations are not the same as those of credit union regulations though both businesses appeal to consumers looking for non-bank financing options. Fortunately, for pawnshops that are generally small businesses with fewer financial resources, their regulations are generally easier to read than those of credit unions. Furthermore, the readability of pawnbroker regulations is not consistent with more broad-based measures of state-level business environments. Collectively these results provide evidence that the regulatory environment for pawnbrokers is unique and merits further empirical investigation.

This study contributes to the relatively small amount of pawnshop research; however, its limitations create opportunities for future research. First, we are unaware of any data source that contains the average education levels of pawnshop owners by state. Subsequent research on pawnshop owner's education levels (along with other characteristics) would assist in the understanding of these small businesses. Second, readability scores cannot control for the rules and procedures within the analyzed document. Future content analysis research of the pawnshop regulations would help augment the knowledge of the regulatory environment both relative to other industries and across states.

\section{REFERENCE}

Baptista, R., Karaoz, M., \& Mendonca, J. (2014). The impact of human capital on the early success of necessity versus opportunity-based entrepreneurs. Small Business Economics, 42(4), 831-847.

Bell, C. (2016). Creditunions: Where free checking still reigns. Retrieved January, 2017 from http://www.bankrate.com/finance/checking/want-free-checking-check-outcredit-unions-1.aspx.

Bos, M., Carter, S. P., \& Skiba, P. M. (2012). The pawn industry and its customers: The United States and Europe. Vanderbilt Law \& Economics Research Paper No. 12-26.

Burger, A. E., \& Zellmer, M. (1995). Strategic opportunities in serving low to moderate income members. Madison, W. I.: Filene Research Institute.

Campbell, N. D., Heriot, K. C., Jauregui, A., \& Mitchell, D. T. (2012). Which state policies lead to U.S. firm exits? Analysis with the economic freedom index. Journal of Small Business Management, 50(1), 87-104.

Caskey, J. (1991). Pawnbroking in America: The economics of a forgotten credit market. Journal of Money, Credit \& Banking, 23(1), 85-99.

Chandler, G. N., \& Hanks, S. H. (1998). An examination of the sustainability of founders human and financial capital in emerging business ventures. Journal of Business Venturing, 13(5), 353-369.

CNBC (2016). America's Top States for Business 2016. Retrieved March, 2017 from http://www.cnbc.com/2016/07/12/americas-top-states-for-business-2016-thelist-and-ranking.html. 
Coleman, S. (2004). The role of education and experience in small firm access to bank loans: Is there a link? Journal of Business \& Entrepreneurship, 16(1), 1-16.

Coy, S. P., \& Shipley, M. F. (2004). Entrepreneurs and educational choice: Is a collegeeducated entrepreneur a more capable entrepreneur? Journal of Business \& Entrepreneurship, 16(2), 37-54.

Fraser Institute (2016). Economic freedom of North America 2016. Retrieved March, 2017 from https://www.fraserinstitute.org/studies/economic-freedom-of-northamerica-2016.

Ganotakis, P. (2012). Founders' human capital and the performance of UK new technology based firms. Small Business Economics, 39(2), 495-515.

General Accounting Office (GAO) (1994, December 7). Tax administration: IRS efforts to improve forms and publications. Washington, D. C., United States: GAO/GGD-9534 Form \& Publication Improvement.

Hanke, S. A., Di, H., \& Miller, G. M. (2012). An analysis of tax court cases relevant to financial planners. Journal of Academy of Business \& Economics, 12(4), 75-83.

IBISWorld (2017). U.S. Industry Reports. Retrieved October, 2017 from https://www.ibisworld.com/all-reports/market-research/\#industryReports.

Johnson, R. W., \& Johnson, D. P. (1998). Pawnbroking in the U.S.: A profile of customers. Washington, District of Columbia: Georgetown University of Business, Credit Research Center.

Kangasharju, A., \& Pekkala, S. (2002). The role of education in self-employment success in Finland. Growth \& Change, 33(2), 216-237.

Klare, G. R. (1974). Assessing readability. Reading Research Quarterly, 10(1), 62-102.

Liang, K. (C. L.), \& Dunn, P. (2014, Fall). Examining entrepreneurial characteristics, motivations, barriers, and outcomes for small versus large multifunctional farm enterprises in New England. Journal of Business \& Entrepreneurship, 26(2), 65-94.

Lussier, R. N. (1995). A nonfinancial business success versus failure prediction model for young firms. Journal of Small Business Management, 33(1), 8-20.

Microsoft.com (2010). Test your document's readability. Retrieved from https:/ / support.office.com/en-ie/article/Test-your-document-s-readability85b4969e-e80a-4777-8dd3-f7fc3c8b3fd2.

National Pawnbrokers Association (2017, January). Pawn industry statistics. Retrieved January, 2017 from https://www.nationalpawnbrokers.org/about/pawnindustry-faqs/.

National Small Business Poll (2017). Regulations. Retrieved June, 2017 from http://www.nfib.com/content/press-release/national/half-of-small-businessessay-regulations-are-a-problem-nfib-research-finds-2/.

Rhode Island (2013a). Office of regulatory reform: Findings of the 2013 small business survey. Retrieved January, 2018 from http://www.omb.ri.gov/reform/reports/ index.php.

Rhode Island (2013b). Office of regulatory reform: Period one of regulatory look back report. Retrieved January, 2018 from http://www.omb.ri.gov/reform/reports/ index.php.

Rogoff, E. G., Lee, M. S., \& Suh, D. C. (2004). Who done it? Attributions by entrepreneurs and experts of the factors that cause and impede small business success. Journal of Small Business Management, 42(4), 364-376.

Shackman, J. D., \& Tenney, G. (2006). The effects of government regulations on the supply of pawn loans: Evidence from 51 jurisdictions in the U. S. Journal of Financial Services Research, 30(2), 69-91. 
U. S. Economic Census (2017, January). Industry snapshot: All other nondepository credit intermediation. Retrieved from https://thedataweb.rm.census.gov/The DataWeb_HotReport2/econsnapshot/2012/snapshot.hrml?NAICS=522298.

Unger, J. M., Rauch, A., Frese, M. \& Rosenbusch, N. (2011). Human capital and entrepreneurial success: A meta-analytical review. Journal of Business Venturing, 26(3), 341-358.

Urbancic, F. R., \& Hsu, K. (2007). The income tax instructions of states in the northeast: A readable study. Clarion Business \& Economic Review, 6(1), 67-79. 